\title{
DIVERSITY AND ABUNDANCE OF INSECT FAUNA IN THE BHAWAL AND MADHUPUR SAL FORESTS OF BANGLADESH
}

\author{
Chowdhury, M. A. K. and M. A. Bashar ${ }^{1}$ \\ Department of Zoology, Life and Earth Science Group, National University, Gazipur-1704, Bangladesh; \\ ${ }^{1}$ Department of Zoology, University of Dhaka, Dhaka-1000, Bangladesh
}

\begin{abstract}
The abundance and diversity of insect fauna were studied from two deciduous sal forests of Bhawal and Madhupur located at central part of Bangladesh. A total of 544 individuals of insects of 61 species belonging to 54 genera, 33 families and 11 orders have been identified with Hymenoptera (31\%) as the dominant order in species richness followed by Coleoptera (13\%), Orthoptera (11\%), Diptera (10\%), Hemiptera (8\%), Lepidoptera (8\%), Odonata (8\%), Homoptera (3\%), Isoptera (3\%), Neuroptera (3\%) and Dictyoptera (2\%). Bhawal scores higher Shannon-Weaver diversity index $\left(\mathrm{H}^{\prime}=3.725\right)$ compared to Madhupur $\left(\mathrm{H}^{\prime}=3.340\right)$. The Bhawal Sal Forest with the collected $341(63 \%)$ insects and identified $53(59 \%)$ species belonging to 10 orders was found more diverse in species richness than the Madhupur Sal Forest with $37(41 \%)$ species belonging to 11 orders identified from the collected $203(37 \%)$ insect samples. Insects of the order Neuroptera were not recorded from Bhawal. Off the 61 species, 29(48\%) species were common in both the forests, 24(39\%) species were exclusive to Bhawal and eight (13\%) species were exclusive to the Madhupur Sal Forest. Apis cerana of Hymenoptera was identified as the dominant species having $9 \%$ of the identified samples followed by dipteran species Musca domestica with 6\% of the samples. Among the insect species 30 (49\%) species were found playing beneficial role as biological control agents, predators, pollinators, honey producers and also organic debris recycler. On the other hand, 31(51\%) species were found to be harmful causing damage to forest vegetation as well as human and wildlife at variable degrees.
\end{abstract}

Key words: Insects; Species; Fauna; Forest; Abundance; Biodiversity.

\section{INTRODUCTION}

Biodiversity is the variation of life and performs a variety of ecological services in an ecosystem, which support one another and work together to form a stable and sustainable ecosystem (Woodcock et al. 2014). Biodiversity encompasses functioning that intact plant and animal communities and the processes that affect them (Kulshrestha and Jain 2016). Therefore, diversity is a central characteristic of natural ecosystems and facilitates these systems to be resilient and able to survive major changes (Jankielsohn 2018).

Insects represent many different trophic niches (Gullan and Cranston 2010) and connect innumerable other organisms in relationships that range from pollination to predation (Losey and Vaughan 2006) and competitive interactions among plants (Forister et al. 2019). Around $72 \%$ of the world's crops are dependent on insects for pollination (Dicke 2017) and therefore contribute to plant diversity. The loss of these pollination services would have adverse effects on food production and no doubt, on the maintenance of biodiversity (Klein et al. 2007).

A few insects are harmful and cause enormous losses each year in agricultural crops, stored products, and health of man and animals (Borror et al. 1989). Termites are the most economically important insects, being the most destructive insect pests of wood and other cellulose products. On the other hand, herbivorous insects with the potential of becoming pests, and could damage $18 \%$ of world agricultural production (Losey and Vaughan 2006).

The tropical moist deciduous Sal (Shorea robusta) forest ecosystem of central Bangladesh is currently in a critical situation. Destructive anthropogenic and natural impacts coupled with over exploitation of forest resources and rapidly expanding agriculture in the forest land is a significant threat 
to the Sal forest ecosystem. The diversity of insect species is a function of the environmental condition (Yi et al. 2012) and understanding the mechanisms that drive biodiversity across spatial and temporal scales is a fundamental goal of ecology. The occurrence and abundance of insects may directly reflect environmental changes (Wahizatul et al. 2011).

As substantial knowledge gaps prevail in relation to insect diversity patterns and the conservation of insect diversity is a topic of global importance. Species diversity is the precondition to maintain the ecosystem services of the nature. It is argued that progress in estimating insect diversity and in understanding insect community dynamics will be enhanced by building local inventories of species diversity, and in the descriptive and experimental studies of the trophic structure of communities. But, the incompleteness of knowledge and the limitation of resources increase the difficulty of work on insect diversity (Danks 1996).

Bangladesh is enriched with entomofauna having representatives of all the insect orders (Nasiruddin and Hoque 2015). However, only few works on insect diversity and abundance have been done in Bangladesh. Thus, in order to increase our practical knowledge on the variety of insects, some basic research works, viz. diversity and abundance are needed. Therefore, the current study is designed to document diversity and abundance of insects and also to determine the dominant insect group in the Bhawal and Madhupur Sal Forests. This information will give an insight into the insect species richness of Sal forests ecosystem that is very critical for management and conservation purposes. By understanding the important functions of insects in natural ecosystems can help to accommodate insects to increase the functional diversity of the forest ecosystems. To perform a research of insect species richness and distribution is a tremendously crucial and precious endeavour. However, it's far real that this cumbersome job cannot be done through a single venture.

\section{MATERIAL AND METHODS}

Present investigation was carried out as part of an ongoing grand programme for the conservation of diversity of insects, butterflies and wildlife as a whole in the natural habitats of Bangladesh. Present study was done at 10 selected study sites (five from each) of two deciduous moist Sal Forests of Bhawal and Madhupur twice in a month at each station on weekly survey basis in all months of the year. The Bhawal Sal Forest is situated in Gazipur District, $40 \mathrm{Km}$ North of Dhaka City on both side of Dhaka-Mymensingh highway and its GPS location is $24^{\circ} 01^{\prime} \mathrm{N}, 90^{\circ} 20^{\prime} \mathrm{E}$. The Madhupur Sal Forest is situated in the Madhupur Upazila of Tangail District, $120 \mathrm{Km}$ North of Dhaka City. It is located between $23^{0} 50^{\prime}-24^{0} 50^{\prime} \mathrm{N}$ latitude and $89^{0} 54^{\prime}-90^{0} 50^{\prime} \mathrm{E}$ longitude. The Sal forest ecosystem facilitates a rich association of undergrowth and diverse variety of flora and fauna.

Table 1. Varieties of equipment used for different habitats and insects.

\begin{tabular}{llll}
\hline Habitat & Example of insects & Equipment/Technique \\
\hline $\begin{array}{l}\text { Ground and low-lying } \\
\text { vegetation }\end{array}$ & $\begin{array}{l}\text { Moths, grasshoppers, cockroaches, mantids and } \\
\text { beetles }\end{array}$ & Sweep net \\
\hline Air & Butterflies, bees, dragonflies, dipterans, neuropterans & Aerial net \\
\hline $\begin{array}{l}\text { Ground, trees and } \\
\text { branches }\end{array}$ & $\begin{array}{l}\text { Ants, termites, beetles, also crawling and dwelling } \\
\text { insects }\end{array}$ & $\begin{array}{l}\text { Handpick and manual } \\
\text { collection using forceps }\end{array}$ \\
\hline
\end{tabular}

Sweep net, aerial net, handpick methods and visual observations were followed to document insects seen between $7.30 \mathrm{hrs}$. and $18.00 \mathrm{hrs}$. and sometimes up to $19.00 \mathrm{hrs}$. according to Bangladesh Standard Time (BST) format. Not all insect groups were studied but the major and commonly occurring orders, viz. Odonata, Orthoptera, Dictyoptera, Isoptera, Hemiptera, Coleoptera, Diptera, Lepidoptera and Hymenoptera were collected from below the canopy layer where the insects were within the reach of the 
aerial nets. Collection of different insects belonging to different orders and families were done by using a variety of collection equipment and methods because of the diversity in their habitat as presented in Table 1. Relevant details, such as the binomial name and ecosystem of collected insects, and other suitable data of the insects were recorded. Insects were collected by aerial nets (in flight), sweeping nets (low vegetation) and handpicking with the help of large forceps for crawling insects. Insects were netted from various places while on the wings or when settled on flowers, puddles and over-ripe fruits.

After capturing, the collected insects were either kept in vials with $70 \%$ Ethyl alcohol or transferred into killing jars that contained cotton soaked with Chloroform (Trichloromethane) and then transported to the laboratory where the specimens were sorted on the basis of the principal morphological characteristics of each insect taxon. Large and hard insects were pinned and dried (for 15 days), and relatively small insects were mounted on paper triangles. Dry preserved samples were labelled and stored in well-sealed wooden insect boxes with naphthalene balls in the Environmental Biology and Biodiversity Laboratory (EBBL), Department of Zoology, Dhaka University. The collected insects were photographed by using camera (Sony Cyber-Shot DSC-H50 and Olympus E-1 Zoom Digital Camera). Insects encountered were identified following Borror et al. (1989) and Bashar (2014).

For computing different indices following formulae were adopted

I. Species richness represents the number of Taxa (species). It is calculated by

a. $D=\frac{S}{\sqrt{N}}$; Where, $D$ is the species richness, $S$ is the number of individuals of a particular species and $N$ is the total number of individuals.

b. Margalef's Index $(\mathrm{R} 1)=\mathrm{S}-1 / \ln (\mathrm{n})$; Where, $\mathrm{S}=$ The total number of species in a community and $\mathrm{n}=$ Total number of Individuals observed and $\ln =$ normal $\log$

II. For calculating the diversity index

$\alpha$-diversity: The $\alpha$-diversity of insect species across seasons and across sites of a habitat was calculated using Shannon-Weaver Index $\left(\mathrm{H}^{\prime}\right) ; \mathrm{H}^{\prime}=\Sigma \mathrm{Pi}(\log P i)$; where, $\mathrm{pi}=\mathrm{ni} / \mathrm{N}$; and 'ni' is the number of individuals of ith species, and $\mathrm{N}=\Sigma \mathrm{ni}$

$\beta$-diversity: The $\beta$-diversity for comparing diversity between two habitats was calculated using Simpson's diversity index by the equation; $\lambda=\frac{\Sigma \mathrm{n}(\mathrm{n}-1)}{\mathrm{N}(\mathrm{N}-1)}$; Where, $\mathrm{n}$ is the number of individuals or amount of each species and $\mathrm{N}$ is the total number of individuals for a site.

III. Pielou's Evenness Index (e): Represents the relative abundance of species in the study area, $\mathrm{J}^{\prime}=\mathrm{H}^{\prime} / \operatorname{lnS}$; Where, $\mathrm{S}$ is the total of number of species observed in different seasons (species richness) and $\ln =$ normal log.

IV. Simpson's Dominance Index (DI): Species dominance across habitats was estimated by Simpson's dominance index; $\mathrm{DI}=1-\{\Sigma \mathrm{ni}(\mathrm{n}-1) / \mathrm{N}(\mathrm{N}-1)\}$; Where, $\mathrm{n}$ is the total number of individuals of a particular species and $\mathrm{N}$ is the total number of individuals of all species. This index ranges between 0 and 1 where, 1 constitutes infinite diversity and 0 , no diversity.

V. Sorensen's Similarity Index (SI): Similarity Index $(\mathrm{SI})=\frac{2 C}{A+B}$; where, $\mathrm{C}=$ Number of species common in both the sites/ communities, $\mathrm{A}=$ Number of species present only at Site-I, and B = Number of species present only at Site-II.

VI. Bray-Curtis Dissimilarity index (BC):

Bray-Curtis Dissimilarity index (BC) was calculated to quantify the compositional dissimilarity between two areas. The result is often multiplied by 100 and treated as percentage. The value is given by:

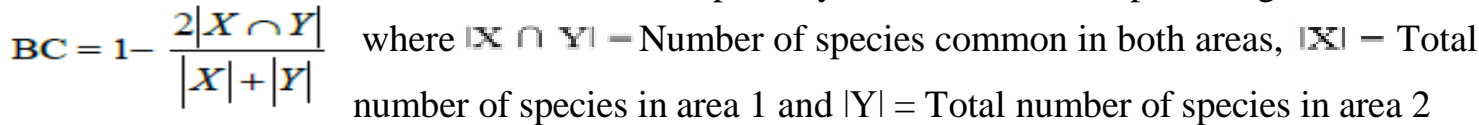


All statistical analyses were performed using IBM SPSS version 24 and PAST version 3 online statistical packages following Kirkman (1996) and Wessa (2007).

\section{RESULTS AND DISCUSSION}

The species composition and number of individual insects recorded from the two deciduous Sal forests of Bhawal and Madhupur is presented inTable 2. A total of 544 individuals of insects of 61 species belonging to 54 genera, 33 families and 11 orders were observed during the present survey. Among the insects' orders Hymenoptera with 18 species and 180 insect samples was the most specious order followed by Coleoptera with eight species and 61 samples, and Orthoptera with seven species and 65 samples. Apis cerana of Hymenoptera was identified as the dominant species having a species richness value of 2.14 followed by dipteran species Musca domestica and hymenopteran Camponotus rufoglaucus with 1.50 and 1.11 , respectively.

Table 2. Diversity of insect fauna in Bhawal and Madhupur Sal Forests with species richness.

\begin{tabular}{|c|c|c|c|c|c|c|}
\hline Order & Family & Genera & Species & Common name & Habitat & $\begin{array}{l}\text { Species } \\
\text { richness }\end{array}$ \\
\hline \multirow{8}{*}{ Coleoptera } & \multirow{2}{*}{ Coccinelidae } & Coccinella & C. transversalis Fabricius & $\begin{array}{l}\text { Transverse } \\
\text { ladybird beetle }\end{array}$ & BSF, MSF & 0.686 \\
\hline & & Epilachna & $\begin{array}{l}\text { Ep. vigintioctopunctata } \\
\text { (Fabricius) }\end{array}$ & $\begin{array}{l}\text { Epilachna } \\
\text { ladybird beetle }\end{array}$ & BSF, MSF & 0.643 \\
\hline & Endomychidae & Ancylopus & A. melanocephalus Olivier & Fungus beetle & BSF & 0.171 \\
\hline & \multirow{5}{*}{ Cicindelidae } & Cicindela & C. aurulenta Fabricius & $\begin{array}{l}\text { Golden-spotted } \\
\text { tiger beetle }\end{array}$ & BSF, MSF & 0.34 \\
\hline & & & C. octonotata Wiedemann & Tiger beetle & BSF, MSF & 0.257 \\
\hline & & Mylabris & M. cichorri Pallas & Blister beetle & BSF, MSF & 0.128 \\
\hline & & Hypomeces & H. squamosus Fabricius & Gold-dust Beetle & BSF & 0.214 \\
\hline & & Anthophila & A. aegyptiaca Zeller & Dung beetle & $\mathrm{BSF}$ & 0.171 \\
\hline Dictyoptera & Meloidae & Mantis & M. religiosa (Linnaeus) & Praying mantis & BSF, MSF & 0.343 \\
\hline \multirow{6}{*}{ Diptera } & \multirow{3}{*}{$\begin{array}{l}\text { Curculionidae } \\
\text { Scarabaeidae }\end{array}$} & Aedes & Ae. albopictus Skuse & $\begin{array}{l}\text { Asian tiger } \\
\text { mosquito }\end{array}$ & MSF & 0.857 \\
\hline & & Armigeres & Ar. flavus Theobald & Jungle mosquito & MSF & 0.514 \\
\hline & & Toxorhynchites & To. bengalensis Theobald & Predator mosquito & MSF & 0.214 \\
\hline & Tabanidae & Tabanus & Ta. rubidus Wiedemann & Horse fly & BSF & 0.643 \\
\hline & Muscidae & Musca & M. domestica Linnaeus & Housefly & BSF, MSF & 1.50 \\
\hline & Calliphoridae & Lucilla & L. sericata (Meigen) & Green Bottle fly & BSF, MSF & 0.514 \\
\hline \multirow{5}{*}{ Hemiptera } & \multirow{2}{*}{ Pentatomidae } & Nezara & N. viridula (Linnaeus) & Green stink bug & BSF MSF & 0.643 \\
\hline & & Eurydema & E. pulchrum (Westwood) & Radish bug & BSF & 0.343 \\
\hline & \multirow{3}{*}{ Reduviidae } & Polytoxus & P. fuscovittus Stal & Assassin bug & BSF & 0.128 \\
\hline & & Euagoras & Eu. plagiatus Burmeister & Asian assassin bug & BSF & 0.128 \\
\hline & & Rhinocoris & R. segmentarius Hahn & Assassin bug & BSF & 0.171 \\
\hline \multirow{2}{*}{ Homoptera } & Cicadidae & Dundubia & D. ensifera Bloem \& Duffels & Green cicadas & BSF, MSF & 0.643 \\
\hline & Aphididae & Aphis & Ap. gossypii Glover & Aphid & MSF & 0.514 \\
\hline \multirow{7}{*}{ Hymenoptera } & \multirow{5}{*}{ Apidae } & \multirow{2}{*}{ Apis } & A. cerana Fabricius & Asiatic honey bee & BSF, MSF & 2.144 \\
\hline & & & A. dorsata Fabricius & Giant honey bee & BSF, MSF & 0.686 \\
\hline & & \multirow{3}{*}{ Xylocopa } & X. aestuans Linnaeus & Carpenter bee & BSF, MSF & 0.257 \\
\hline & & & $X$. latipes Drury & Tropical carpenter bee & BSF, MSF & 0.171 \\
\hline & & & $X$. rufa Friese & Bumble bee & BSF, MSF & 0.214 \\
\hline & Megachilidae & Megachile & M. disjuncta Fabricius & $\begin{array}{l}\text { Megachile leaf- } \\
\text { cutter }\end{array}$ & BSF, MSF & 0.171 \\
\hline & Formicidae & Camponotus & $\begin{array}{l}\text { C. rufoglaucus Jerdon } \\
\text { C. festinus Smith }\end{array}$ & $\begin{array}{l}\text { Velvet sugar ant } \\
\text { Carpenter ant }\end{array}$ & $\begin{array}{l}\text { BSF, MSF } \\
\text { BSF }\end{array}$ & $\begin{array}{l}1.114 \\
0.128\end{array}$ \\
\hline
\end{tabular}




\begin{tabular}{|c|c|c|c|c|c|c|}
\hline \multirow[t]{10}{*}{ Hymenoptera } & & Cromastoogstor & Cr. abdominalis & The Saint & BSF, MSF & 0.6 \\
\hline & & & Cr. rufa Jerdon & Red wood ant & BSF & 0.085 \\
\hline & & Myrmica & My. indica Weber & Red fire ant & BSF & 0.343 \\
\hline & & Trichomyrmex & Tr. criniceps Mayr & $\begin{array}{l}\text { Destructive } \\
\text { trailing ant }\end{array}$ & BSF & 0.085 \\
\hline & & Odontoponera & O. denticulata Mayr & Toothed ant & BSF, MSF & 0.514 \\
\hline & & Tetraponera & Te. nigra Jerdon & Black slender ant & BSF & 0.257 \\
\hline & & Solenopsis & S. geminata Fabricius & Tropical fire ant & BSF & 0.257 \\
\hline & & Pheidole & Ph. binghamii Forel & Big headed ant & BSF & 0.214 \\
\hline & \multirow{2}{*}{ Vespidae } & Vespa & V. tropica Smith & $\begin{array}{l}\text { The greater } \\
\text { banded hornet }\end{array}$ & BSF & 0.171 \\
\hline & & Polistes & Po. olivaceus De Geer & $\begin{array}{l}\text { The yellow paper } \\
\text { wasp }\end{array}$ & BSF & 0.3 \\
\hline \multirow[t]{2}{*}{ Isoptera } & \multirow[t]{2}{*}{ Termitidae } & Odontotermes & $\begin{array}{l}\text { Od. parvidens Holmgren \& } \\
\text { Holmgren }\end{array}$ & Live wood termite & BSF, MSF & 0.343 \\
\hline & & Microtermes & Mi. obesi Holmgren & Live wood termite & BSF, MSF & 0.257 \\
\hline \multirow{5}{*}{ Lepidoptera } & \multirow{2}{*}{ Saturniidae } & Cricula & Cr. trifenestra Helfer & Mango defoliator & MSF & 0.085 \\
\hline & & Attacus & At. atlas Linneaus & Atlas moth & BSF & 0.042 \\
\hline & Noctuidae & Rhesala & Rh. imparata Walker & Albizia defoliator, & BSF, MSF & 0.428 \\
\hline & Geometridae & Antitrygodes & An. cuneilinea Walker & $\begin{array}{l}\text { Cadamba } \\
\text { defoliators }\end{array}$ & MSF & 0.214 \\
\hline & Crambidae & Eutectona & Eu. machaeralis (Walker) & Teak skeletonizer & MSF & 0.128 \\
\hline \multirow{2}{*}{ Neuroptera } & Corydalidae & Neochauliodes & Ne. simplex (Walker) & Alder fly & MSF & 0.343 \\
\hline & Chrysopidae & Chrysoperla & Ch. carnea Stephens & Green lace wing & MSF & 0.171 \\
\hline \multirow{5}{*}{ Odonata } & \multirow{3}{*}{ Libellulidae } & $O r$ & Or. sabina Drury & Slender skimmer & BSF & 0.343 \\
\hline & & $O r$ & Or. testaceum (Burmeister) & Skimmer & BSF & 0.171 \\
\hline & & Urothemis & Ur. signata (Rambur) & Skimmer & BSF & 0.171 \\
\hline & Gomphidae & Actinogomphus & Ac. rapax (Rambur) & Common Clubtail & BSF, MSF & 0.257 \\
\hline & Coenagriidae & Ischnura & I. aurora (Brauer) & Golden Dartlet & BSF & 0.085 \\
\hline \multirow{7}{*}{ Orthoptera } & \multirow{2}{*}{ Acrididae } & Choroedocus & C. robustus (Serville) & $\begin{array}{l}\text { Short horned } \\
\text { grasshopper }\end{array}$ & BSF, MSF & 0.728 \\
\hline & & Oxya & O. japonica (Thunberg) & $\begin{array}{l}\text { Short horned } \\
\text { grasshopper }\end{array}$ & BSF & 0.214 \\
\hline & \multirow{2}{*}{ Gryllidae } & Gryllus & G. confirmatus (Walker) & Cricket & BSF, MSF & 0.214 \\
\hline & & Brachytrypes & B. orientalis Burmeister & Field cricket & BSF, MSF & 0.343 \\
\hline & \multirow{2}{*}{ Gryllotalpidae } & Gryllotalpa & Gr. orientalis Burmeister & Asian mole cricket & BSF, MSF & 0.343 \\
\hline & & Euscyrtus & E. concinnus De Haan & Crickets & BSF & 0.171 \\
\hline & Tettigoniidae & Conocephalus & C. longipennis De Haan & $\begin{array}{l}\text { Meadow } \\
\text { Grasshopper }\end{array}$ & BSF, MSF & 0.771 \\
\hline
\end{tabular}

$\mathrm{BSF}=$ Bhawal Forest and MSF= Madhupur Sal Forest

The Bhawal Sal Forest with the collected 341 (63\%) insects and identified 53 (59\%) species belonging to 10 orders was found more diverse in species richness than the Madhupur Sal Forest with $37(41 \%)$ species belonging to 11 orders identified from the collected 203 (37\%) insect samples (Fig. 1 and 2). Insects of the order Neuroptera was not recorded from Bhawal.

There was a significant association between insect population of Bhawal and Madhupur Sal Forests $\left(\mathrm{F}=6.40, \mathrm{P}=0.012<0.05\right.$ and $\left.\chi^{2}=184.94, \mathrm{P}=0.001<0.001\right)$. But there was also a significant difference between insect population of the two forests $(\mathrm{t}=8.09, \mathrm{P}=0.012<0.05$ with a mean of $5.59 \pm 0.69)$ for Bhawal and $(\mathrm{t}=5.85, \mathrm{P}=0.012<0.05$ with a mean of 5.85 \pm 0.57$)$ for Madhupur, and the mean difference between the populations of two forests was 2.26 (Table 3). This was also revealed in the result of Mann- 
Whitney Test $(\mathrm{U}=1202.5$ and $\mathrm{Z}=3.41, \mathrm{P}=0.000<0.001)$. There was also a strong correlation in the occurrence of insect fauna among different orders in the two deciduous sal forests).

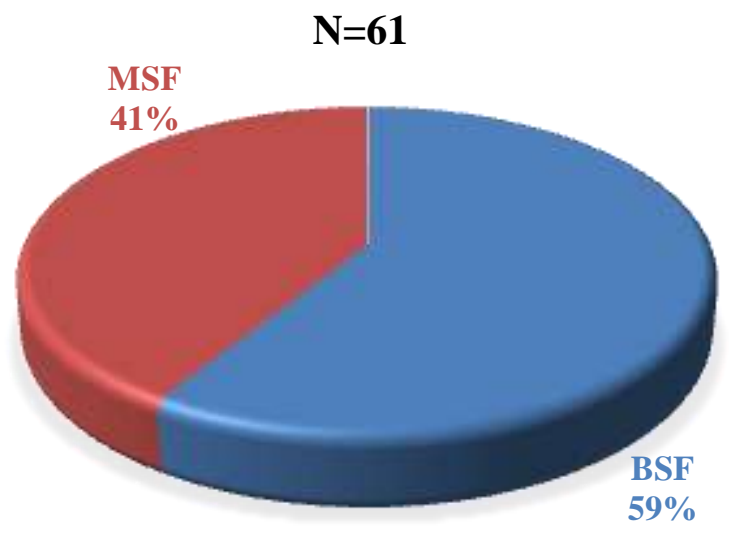

Fig 1. The relative composition of species

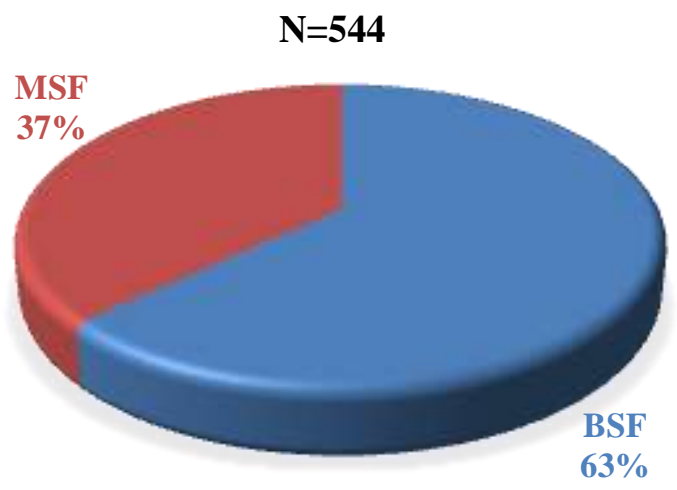

Fig. 2. The relative composition of insects $\mathrm{BSF}=$ Bhawal Forest and MSF= Madhupur Sal Forest

Sixty-one species of insects of 11 orders other than butterflies encountered during the present study are shown in Fig. 3. The maximum abundant insect order was Hymenoptera which encountered $31 \%$ of species followed by Coleoptera (13\%), Orthoptera (11\%), Diptera (10\%,) Lepidoptera (8\%), Hemiptera $(8 \%)$ and Odonata $(8 \%)$. The least number of species was recorded from the Order Dictyoptera with a single (2\%) species. However, Hymenoptera was also the most abundant insect Order with 180 insects (34\%) followed by Diptera (18\%) and Orthoptera (12\%); the least abundant order was Dictyoptera (1\%) (Fig. 4).

Table 3. Results of Test of significance of insect orders of Bhawal and Madhupur Sal Forests.

\begin{tabular}{|c|c|c|c|}
\hline \multicolumn{4}{|c|}{ Test of significance } \\
\hline Variables & BSF & MSF & Sig. \\
\hline Mean & 5.59 & 3.38 & \\
\hline Std. error & 0.69 & 0.57 & $0.000 * *$ \\
\hline F Test & & 6.40 & $0.012 *$ \\
\hline $\mathrm{t}$ Test & 8.09 & 5.85 & $0.000 * *$ \\
\hline Mann-Whitney U : & & 1202.5 & $0.000 * *$ \\
\hline Z Test & & 3.41 & $0.000 * *$ \\
\hline $\mathrm{Chi}^{2}$ Test & & 184.94 & $0.0017 *$ \\
\hline Pearson $\mathrm{r}$ & 0.869 & 0.862 & \\
\hline
\end{tabular}

Between the two forests, the Bhawal scores higher Shannon-Weaver diversity index $\left(\mathrm{H}^{\prime}=3.725\right)$ than the Madhupur $\left(\mathrm{H}^{\prime}=3.340\right)$ (Table 4). This means that the Bhawal had higher species diversity (53 species) than Madhupur (37 species) which was also revealed from higher Fisher alpha diversity index for the Bhawal $(\alpha=17.57)$ than the Madhupur $(\alpha=13.25)$. The Evenness Index (e) and Equitability Index $\left(\mathrm{J}^{\prime}\right)$ of both the forests were not significantly different and they are close to 1, denoting that both forests have more or less similar number of species and which are similarly distributed with similar composition and their numbers of individuals are also close to each other. Although the Bhawal Sal Forest has higher number of species compared to the Madhupur Sal Forest, but the effective number of 
species is denoting less difference between the contributions of each species in the biomass of the forests.

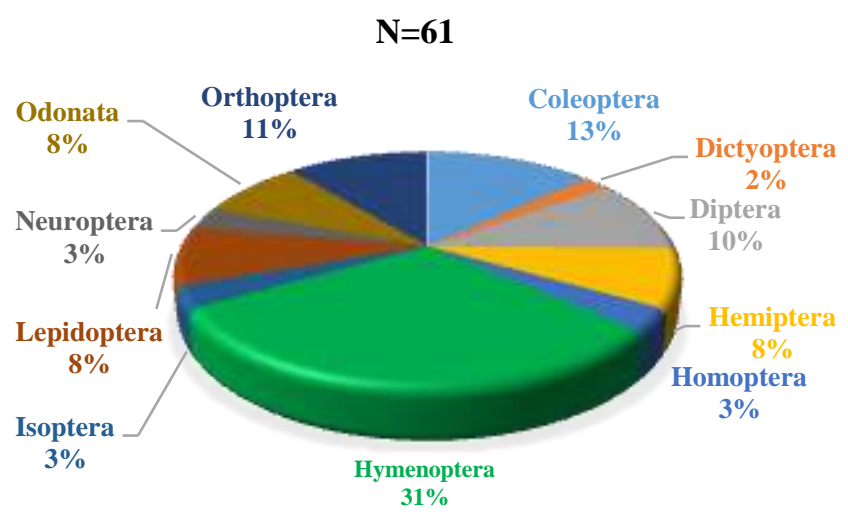

Fig. 3. Relative abundance of the species of different orders.

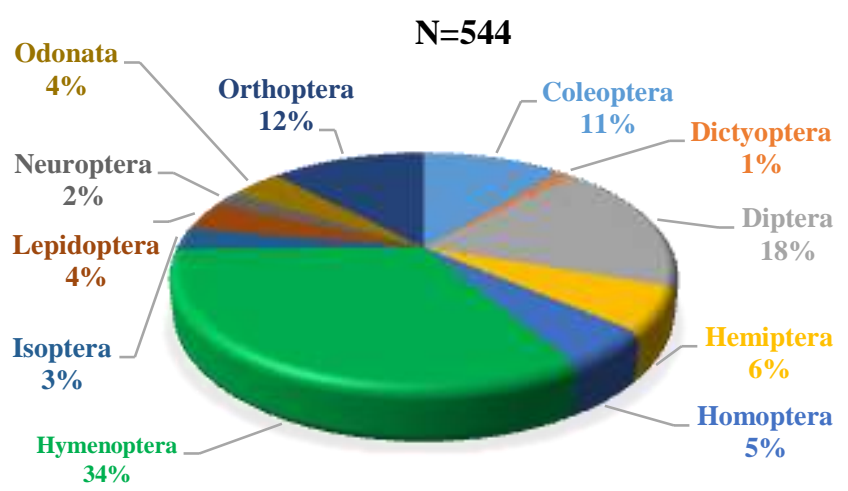

Fig. 4. Relative abundance of the insects of different orders.

However, significant differences existed between the insect fauna of the two forests which was revealed from the Bray-Curtis Dissimilarity Index (BC), and the difference in between the Bhawal and the Madhupur Sal forests was 1.02 . This means that the two forests have $26.66 \%$ dissimilarity in species richness between them.

Table 4. Comparison of the diversity of insect oders between the Bhawal and the Madhupur Sal Forests.

\begin{tabular}{lccc}
\hline Diversity indices & BSF & MSF & Sig. \\
\hline Fisher alpha $(\alpha)$ & 17.57 & 13.25 & $0.000^{* *}$ \\
Shannon index $\left(\mathrm{H}^{\prime}\right)$ & 3.725 & 3.340 & $0.000^{* *}$ \\
Simpson index $(\lambda)$ & 0.968 & 0.954 & $0.006^{*}$ \\
Evenness $(\mathrm{e})$ & 0.783 & 0.763 & 0.648 \\
Margalef $(\mathrm{R} 1)$ & 8.917 & 6.776 & $0.000^{* *}$ \\
Equitability $\left(\mathrm{J}^{\prime}\right)$ & 0.938 & 0.925 & 0.361 \\
Dominance Index $(\mathrm{DI})$ & 0.031 & 0.029 & $0.000^{* *}$ \\
Dissimilarity Index $(\mathrm{BC})$ & 13.84 & 12.82 & $0.000^{* *}$ \\
\hline 0verall average dissimilarity=26.66\% & \multicolumn{3}{c}{} \\
\hline ** Value is significant at P=0.01 and *alue is significant at P=0.05 level \\
\multicolumn{4}{c}{ BSF= Bhawal Forest and MSF= Madhupur Sal Forest }
\end{tabular}

The most abundant order observed in the Bhawal Sal Forest was Hymenoptera (18 species and 133 individuals), followed by Coleoptera ( 8 species and 43 individuals) and Orthoptera (seven species and 42 individuals) (Table 5). Two hundred and three insects belonging to 37 species were recorded from the Madhupur Sal Forest. The most abundant order observed in this forest was also Hymenoptera (nine species and 47 individuals), followed by Diptera (five species and 57 individuals), Coleoptera (five species and 42 individuals) and Orthoptera (five species and 23 individuals). Of the 61 species, 29(48\%) species were common in both the forests, 24(39\%) species were exclusive to the Bhawal and eight (13\%) species being exclusive to the Madhupur Sal Forests.

The species richness and abundance of different insect orders based on diversity, evenness, dominance, similarity, dissimilarity and species richness are presented in Table 6. The highest insect diversity was found in the order Hymenoptera, which had a Shannon-Weaver Diversity Index $\left(\mathrm{H}^{\prime}\right)$ of 1.066. The lowest diversity was observed in Neuroptera $\left(\left(\mathrm{H}^{\prime}=0.276\right)\right.$. Evenness with the greatest value 
being associated with Order Homoptera $\left(\mathrm{J}^{\prime}=0.43\right)$ and the lowest value being went with the Order Dictyoptera $\left(\mathrm{J}^{\prime}=0\right)$. Order Hymenoptera was determined as the dominant group of insect with the Dominant index value of $\mathrm{DI}=0.878$.

Table 5. Relative abundance of the species of different insect Orders in the Bhawal and the Madhupur Sal Forests.

\begin{tabular}{|c|c|c|c|c|c|c|c|}
\hline \multirow[t]{2}{*}{ Order } & \multicolumn{3}{|c|}{ Habitat wise abundance of species } & \multirow[t]{2}{*}{$\begin{array}{l}\text { Total no. } \\
\text { of sp. }(\%)\end{array}$} & \multicolumn{2}{|c|}{$\begin{array}{l}\text { Habitat wise } \\
\text { abundance of insects }\end{array}$} & \multirow{2}{*}{$\begin{array}{l}\text { Relative } \\
\text { occurrence } \\
\text { of insects } \\
(\%)\end{array}$} \\
\hline & $\begin{array}{l}\text { No. of sp. in } \\
\text { common }(\%)\end{array}$ & $\begin{array}{l}\text { Sp. found only } \\
\text { in BSF }(\%)\end{array}$ & $\begin{array}{l}\text { Sp. found only } \\
\text { in MSF }(\%)\end{array}$ & & BSF (\%) & MSF (\%) & \\
\hline Coleoptera & $5(8)$ & $3(5)$ & 0 & $8(13)$ & $43(8)$ & $18(3)$ & $61(11)$ \\
\hline Dictyoptera & $1(2)$ & 0 & 0 & $1(2)$ & $5(1)$ & $3(1)$ & $8(1)$ \\
\hline Diptera & $2(3)$ & $1(2)$ & $3(5)$ & $6(10)$ & $42(8)$ & $57(10)$ & $99(18)$ \\
\hline Hemiptera & $1(2)$ & $4(7)$ & 0 & $5(8)$ & $26(5)$ & $7(1)$ & $33(6)$ \\
\hline Homoptera & $1(2)$ & 0 & $1(2)$ & $2(3)$ & $11(2)$ & $16(3)$ & $27(5)$ \\
\hline Hymenoptera & $9(15)$ & $9(15)$ & 0 & $18(30)$ & $133(24)$ & $47(9)$ & $180(33)$ \\
\hline Isoptera & $2(3)$ & 0 & 0 & $2(3)$ & $9(2)$ & $5(1)$ & $14(3)$ \\
\hline Lepidoptera & $1(2)$ & $2(3)$ & $2(2)$ & $5(8)$ & $12(2)$ & $9(2)$ & $21(4)$ \\
\hline Neuroptera & 0 & 0 & $2(3)$ & $2(3)$ & 0 & $12(2)$ & $12(2)$ \\
\hline Odonata & $2(3)$ & $3(5)$ & 0 & $5(8)$ & $18(3)$ & $6(1)$ & $24(4)$ \\
\hline Orthoptera & $5(8)$ & $2(3)$ & 0 & $7(11)$ & $42(80$ & $23(4)$ & $65(12)$ \\
\hline Total & $29(48)$ & $24(39)$ & $8(13)$ & $61(100)$ & $341(63)$ & $203(37)$ & $544(100)$ \\
\hline
\end{tabular}

$\mathrm{BSF}=$ Bhawal Forest and MSF= Madhupur Sal Forest

Different orders had different indices value in respect of the number of species and individuals due to differences in their food resources, habit and microhabitats The highest species richness was recorded from the order Hymenoptera $(\mathrm{D}=7.716)$ and the lowest from the Order Dictyoptera $(\mathrm{D}=0.342)$. Between the two forests, the Bhawal scores higher Shannon -Weaver Diversity Index for Order Coleoptera, Hemiptera, Hymenoptera, Odonata and Orthoptera compared to the Madhupur which has higher scores for this index for the Orders Diptera, Homoptera, Lepidoptera and Neuroptera. The evenness index denotes that both the forests have the similar distribution patterns of species.

Table 6. Diversity indices of different insect orders.

\begin{tabular}{lcccccccc}
\hline $\begin{array}{l}\text { Insects' } \\
\text { Order }\end{array}$ & \multicolumn{1}{c}{ Diversity indices } \\
\cline { 2 - 9 } & $\begin{array}{c}\text { Shannon- } \\
\text { Wiener index } \\
\left(\mathrm{H}^{\prime}\right)\end{array}$ & $\begin{array}{c}\text { Simpson's } \\
\text { diversity } \\
\text { index }(\lambda)\end{array}$ & $\begin{array}{c}\text { Margalef's } \\
\text { Index }(\mathrm{R} 1)\end{array}$ & $\begin{array}{c}\text { Pielou's } \\
\text { Evenness } \\
\text { Index }\left(\mathrm{J}^{\prime}\right)\end{array}$ & $\begin{array}{c}\text { Simpson's } \\
\text { Dominance } \\
\text { Index }(\mathrm{DI})\end{array}$ & $\begin{array}{c}\text { Sorensen's } \\
\text { Similarity } \\
\text { Index }(\mathrm{SI})\end{array}$ & $\begin{array}{c}\text { Dissimilarity } \\
\text { Index }(\mathrm{BC})\end{array}$ & $\begin{array}{c}\text { Species } \\
\text { richness } \\
(\mathrm{D})\end{array}$ \\
\hline Coleoptera & 0.826 & 0.16 & 7.756 & 0.397 & 0.839 & 3.333 & -2.333 & 2.614 \\
Dictyoptera & 0 & 0.1 & 0.519 & 0 & 0 & 0 & 0.342 & 0.342 \\
Diptera & 0.712 & 0.212 & 5.782 & 0.397 & 0.787 & 1 & 0 & 4.243 \\
Hemiptera & 0.605 & 0.274 & 4.714 & 0.376 & 0.725 & 0.5 & 0.5 & 1.414 \\
Homoptera & 0.298 & 0.4871 & 1.696 & 0.43 & 0.512 & 2 & -1 & 1.157 \\
Hymenoptera & 1.066 & 0.121 & 17.807 & 0.368 & 0.878 & 2 & -1 & 7.716 \\
Isoptera & 0.297 & 0.472 & 1.621 & 0.427 & 0.527 & 0 & 1 & 0.6 \\
Lepidoptera & 0.583 & 0.28 & 4.671 & 0.362 & 0.719 & 0.5 & 0.5 & 0.9 \\
Neuroptera & 0.276 & 0.515 & 1.597 & 0.398 & 0.484 & 0 & 1 & 0.514 \\
Odonata & 0.659 & 0.543 & 4.685 & 0.409 & 0.456 & 1.333 & -0.333 & 1.028 \\
Orthoptera & 0.777 & 0.178 & 6.76 & 0.399 & 0.821 & 5 & -4 & 2.786 \\
\hline
\end{tabular}

Of the 61 species of insects of different orders recorded from the Bhawal and the Madhupur Sal forests, 30 (49\%) species were identified as beneficial playing role as biological control agents, pollinators and honey producers, and also in recycling of organic debris. On the other hand, 31(51\%) 
species were found to be harmful doing damage to forest vegetation as well as human being and other animals at variable degrees. Representatives' of each insect order are presented in Fig. 5.

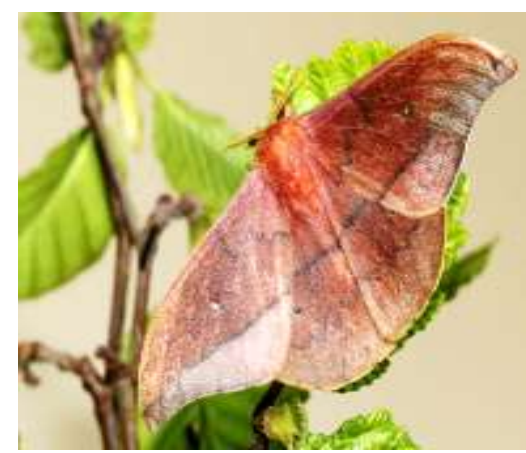

a.

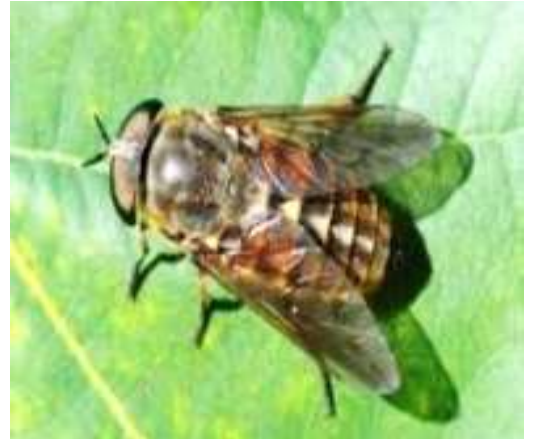

d.

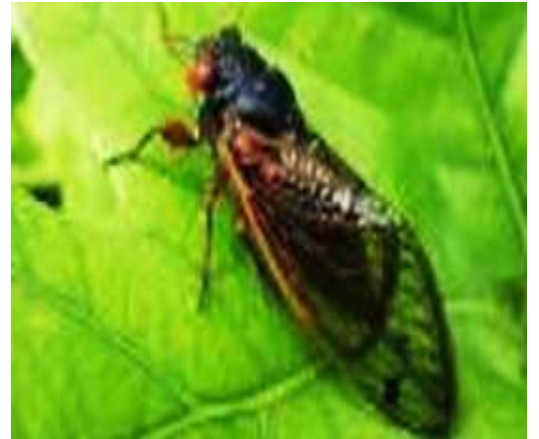

g.

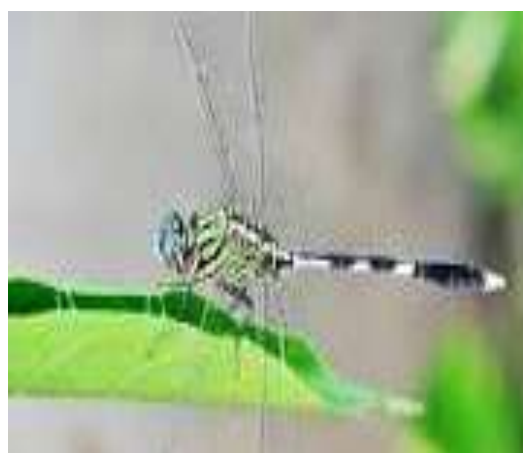

b.

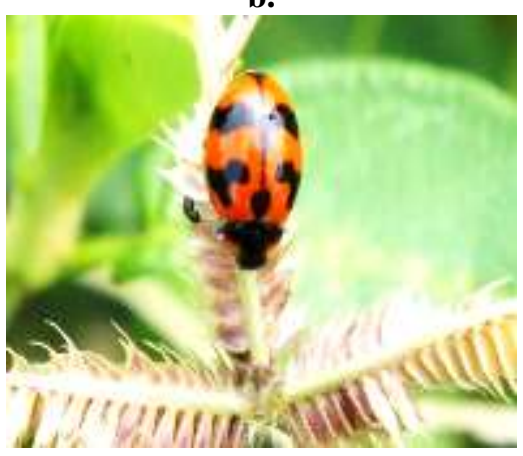

e.

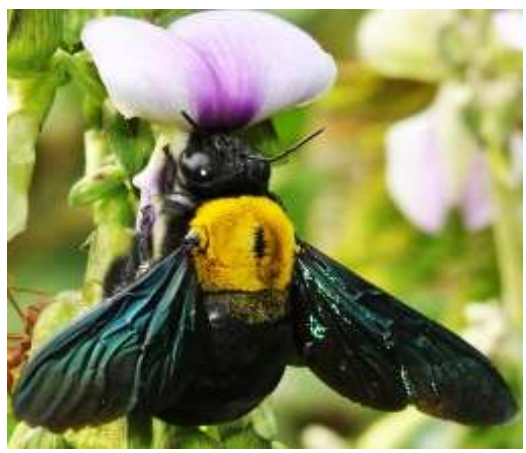

h.

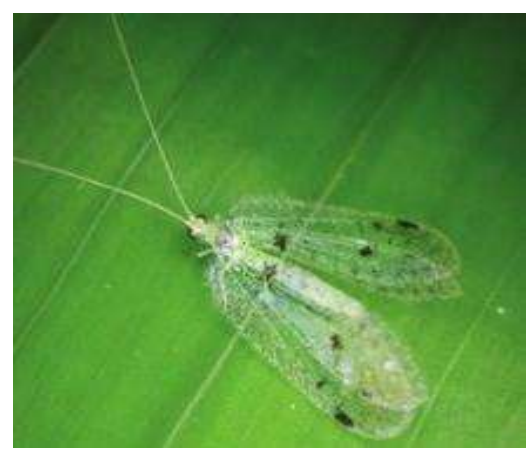

c.

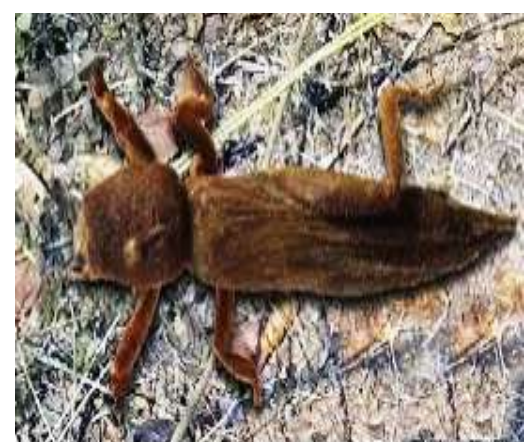

f.

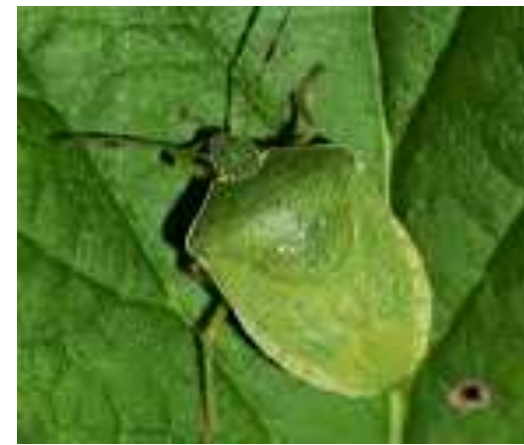

i.

Fig. 5. Pictorial presentation of the insects under different orders recorded from the Bhawal and the Madhupur Sal forests: a. Cricula trifenestra (Saturniidae: Lepidoptera); b. Orthetrum sabina (Libellulidae: Odonata); c. Neochauliodes simplex (Corydalidae Neuroptera); d. Tabanus rubidus (Tabanidae: Diptera); e. Epilachna vigintioctopunctata (Coccinelidae: Coleoptera); f. Gryllus confirmatus (Gryllidae: Orthoptera); h. Xylocopa rufa (Apidae: Hymenoptera); and i. Nezara viridula (Pentatomidae: Hemiptera).

Among the recorded insects 25 species, viz. ants, lady bird beetles, dragon and damsel flies, green lacewings, assassin bugs, preying mantids and wasps belonging to 22 genera 10 families under six orders were recorded as either attendant or predator insects, and also as biological control agents preying upon different insects (Table 7), and five species of two genera, viz. bees and their allies belonged to the family Apidae of Hymenoptera acting as pollinator.

Twenty-six insect species viz. moths, beetles, bugs, hoppers, termites, belonging to 24 genera and 17 families under seven orders were recorded as harmful insects causing much harms to forest plants and 
crops (Table 8) and five species of five genera viz. mosquitoes and flies acted as the vectors and transmitters of diseases to human and wild lives.

Table 7. Taxonomic profile of beneficial insects and their economic importance in the forest habitats.

\begin{tabular}{|c|c|c|c|}
\hline Order & Family & Scientific name & Economic importance \\
\hline \multirow{18}{*}{ Hymenoptera } & \multirow{10}{*}{ Formicidae } & Camponotus rufoglaucus & Attendant of Lycaenidae eggs and larvae \\
\hline & & Cremastogaster abdominalis & \multirow{12}{*}{ Biological control agent } \\
\hline & & C. rufa & \\
\hline & & Myrmica indica & \\
\hline & & Trichomyrmex criniceps & \\
\hline & & Odontoponera denticulata & \\
\hline & & Tetraponera nigra & \\
\hline & & Solenopsis geminata & \\
\hline & & Pheidole binghamii & \\
\hline & & Camponotus festinus & \\
\hline & Megachilidae & Megachile disjuncta & \\
\hline & \multirow{2}{*}{ Vespidae } & Vespa tropica & \\
\hline & & Polistes olivaceus & \\
\hline & \multirow{5}{*}{ Apidae } & Xylocopa aestuans & Pollinator \\
\hline & & $X$. latipes & \\
\hline & & X. rufa & \\
\hline & & Apis serana & Pollinator and produce honey \\
\hline & & A. dorsata & \\
\hline Diptera & Culicidae & Toxorhynchites bengalensis & Biological control agent \\
\hline Coleoptera & Coccinelidae & Coccinela transversalis & Predaceous insect \\
\hline Dictyoptera & Mantidae & Mantis religiosa & \\
\hline \multirow{5}{*}{ Odonata } & \multirow{3}{*}{ Libellulidae } & Orthetrum sabina & \\
\hline & & O. testaceum & \\
\hline & & Urothemis signata & \\
\hline & Gomphidae & Actinogomphus rapax & \\
\hline & Coenagriidae & Ischnura aurora & \\
\hline Coleoptera & Scarabaeidae & Anthophila aegyptiaca & Recycling dung \\
\hline \multirow{2}{*}{ Neuroptera } & Corydalidae & Neochauliodes simplex & \multirow[t]{2}{*}{ Biological control agent } \\
\hline & Chrysopidae & Chrysoperla carnea & \\
\hline Homoptera & Cicadidae & Dundubia ensifera & Food of birds and other animals \\
\hline
\end{tabular}

In the present study, 61 species of insects of 54 genera belonging to 33 families under 11 orders were identified from the Bhawal and the Madhupur Sal Forests. Both the forests have been found to be rich and diverse in insect fauna in the present study. Not many researches have been done on the diversity of insects in Bangladesh. Only some sporadic investigations have been done earlier focusing on economically important insects but broad investigations have not been done so far. Most of the researches have been done on the diversity of butterflies. Bashar (2014 and 2015) identified more than 325 species of butterflies with their taxonomic details and distribution from different forests of Bangladesh.

Rahman and Jahan (2020) investigated the species diversity and richness of ant species from the Bhawal National Park of Bangladesh and identified 42 species, some of which are also recorded in the present study. Earlier Paul et al. (2017) identified 71 species of insects belonging to 45 families under 14 orders from Tea Research Institute, Shreemangal, Moulvibazar, Bangladesh. Although they have recorded them from tea gardens, but some of these insect species including two species of Neuroptera 
were also identified in the present investigation. In a similar study from a palm grove of south-eastern Algeria in different climatic condition, Zakaria et al (2021) inventoried 44 species of entomofauna belonging to nine orders and 27 families with Coleoptera as dominant order followed by Hemiptera and Orthoptera.

Table 8. Taxonomic profile of harmful insects and their economic importance in the forest habitats.

\begin{tabular}{|c|c|c|c|}
\hline Order & Family & Scientific name & Economic importance \\
\hline \multirow{3}{*}{ Lepidoptera } & Saturniidae & $\begin{array}{l}\text { Cricula trifenestra } \\
\text { Attacus atlas }\end{array}$ & Do harm to plants \\
\hline & Noctuidae & Rhesala imparata & \\
\hline & Geometridae & Antitrygodes cuneilinea & \\
\hline \multirow{6}{*}{ Coleoptera } & Coccinelidae & Epilachna vigintioctopunctata & \\
\hline & Endomychidae & Ancylopus melanocephalus & \\
\hline & Cicindelidae & Cicindela aurulenta & \\
\hline & Cicmuendae & C. octonotata & \\
\hline & Meloidae & Mylabris cichorri & \\
\hline & Curculionidae & Hypomeces squamosus & \\
\hline \multirow{6}{*}{ Hemiptera } & Pentatomidae & Eurydema pulchrum & \\
\hline & & Polytoxus fuscovittus & \\
\hline & Reduviidae & Euagoras plagiatus & \\
\hline & & Rhinocoris segmentarius & \\
\hline & Aphididae & Aphis gossypii & \\
\hline & Pentatomidae & Nezara viridula & \\
\hline Isoptera & Termitidae & $\begin{array}{l}\text { Odontotermes parvidens } \\
\text { Microtermes obesi }\end{array}$ & \\
\hline \multirow{5}{*}{ Orthoptera } & Acrididae & $\begin{array}{l}\text { Choroedocus robustus } \\
\text { Oxya japonica }\end{array}$ & \\
\hline & Gryllidae & $\begin{array}{l}\text { Gryllus confirmatus } \\
\text { Brachytrypes orientalis }\end{array}$ & \\
\hline & Gryllotalpidae & Gryllotalpa orientalis & \\
\hline & Gryllotalpidae & Euscyrtus concinnus & \\
\hline & Tettigoniidae & Conocephalus longipennis & \\
\hline Lepidoptera & Crambidae & Eutectona machaeralis & Skeletonizer of leaves of teak \\
\hline \multirow{5}{*}{ Diptera } & Calliphoridae & Lucilla sericata & Transmits disease \\
\hline & Muscidae & Musca domestica & \\
\hline & Tabanidae & Tabanus rubicandus & \\
\hline & Culicidae & Aedes albopictus & \\
\hline & Cumcidae & Armigeres flavus & Vicious bitter in the forest \\
\hline
\end{tabular}

Nasiruddin and Barua (2018) studied the abundance and diversity of odonates from Chittagong University campus of Bangladesh and identified 25 species under three families. In the present study five species of odonates under three families were also identified which are very similar to the above mentioned authors. Jasmin and Miah (2013) identified 19 species of bees belonging to four families of Order Hymenoptera from Chittagong. Akter et al (2019) also identified 11 bee species belonging to two families from Dhaka City of Bangladesh. Five bee species, viz. Apis cerana, A. dorsata, Xylocopa aestuans, $X$. latipes and Megachile disjuncta identified by these authors have also been encountered in the present study.

Gerlach et al. (2013) collected a total of 120 species under 98 genera in 37 families of insects from West Bengal, India and revealed that five orders, viz. Hemiptera, Orthoptera, Lepidoptera, Hymenoptera and Coleoptera showed higher species richness in different habitats compared to other insect orders. 
Ramar et al. (2018) reported the biodiversity and distribution pattern of insects from Sirumallai hills, Eastern Ghats, Tamil Nadu, India and found Hemiptera being dominant order followed by Coleoptera and Odonata. Usha and Vimala (2015) documented a total of 529 individual insects belonging to nine orders and 38 families and 58 species. They found Coleoptera and Lepidoptera as the most dominant orders and Phasmida as the least dominant one. Das et al. (2018) studied the diversity of insect pollinators and found Lepidoptera to be more diverse followed by Hymenoptera, Diptera and Coleoptera from the rabi crop fields in dry season from Barpeta, Assam, India. Chowdhury (2020) has also identified lepidopterans as good pollinators of forest plants.

In the present study, hymenopterans were identified as pollinator contributing to the natural gene flow of plants, odonates and neuropterans as biological control agents, and the dictyopterans and coccinelids were found preying upon other insects. For example, Mantis was found preying upon butterflies and other insects. Some of the insects especially the Lepidoptera and Orthoptera are the food of birds. It appears that, the abundance levels of orthopteran and lepidopteran insects in the forest region may be regulating factors for the local abundance of birds.

The caterpillars of moths and some butterflies, hemipterans, and coleopterans do much harm to the plants either by defoliating them or by sucking cell saps, and sometimes they are believed to be transmitting plant diseases. Many dipterans are blood sucking insects transmitting the parasites of many diseases of men, domestic and wild animals. However, some dipterans are pollinators too.

Almost all insects are highly related with plants in the field of pollination; and are vital contributors to gene flow activity in the field and speciation in plant kingdom as a whole. It is now established in the scientific world that a considerable number of plants have entomophilous pollen and are highly dependent on insects for the increase of their population. On the other hand, some insects are also highly dependent on these entomophilous pollen bearing plants for their existence and sustenance of their population. This interacting condition between plants and insects in a natural forest condition is crucial for maintaining a naturally balanced forest ecosystem and are capable to provide best services to human and other animals.

The present study identified rich insect biodiversity and would help in knowing the species diversity and distribution patterns of insect fauna of the moist deciduous forest lands of Bangladesh. Insects performing critical functions in any ecosystem and the natural ecosystem significantly support the existence of rich insects' species composition. For the sustainable production of insects, the sound environmental and habitat conditions in the natural ecosystems should be conserved. Because, insects are the indicators of the environment and play an important role for gene flow in nature through pollination and ecosystem services. Further studies should be conducted using other sampling techniques with expanded geographical scope to identify other factors affecting the population dynamics of insects.

\section{ACKNOWLEDGEMENTS}

The authors acknowledge the Ministry of Education, Government of the People's Republic of Bangladesh for their financial support to the research programme. They also acknowledge the Forestry Division of the Ministry of Environment, Forest and Climate Change, Government of the People's Republic of Bangladesh for their assistance in conducting the research in the forests of Bangladesh.

\section{REFERENCES}

Akter, T., S. Akther, S. Sultana, J. A. Jhorna and S. Begum. 2019. The bees (Apocrita: Hymenoptera) of Dhaka City, Bangladesh. J. biodivers. conserv. bioresour. manag. 5(1): 113-120. 
Bashar, M. A. 2014. Butterflies of Bangladesh: A broad approach for nature lovers. Vol. 1. 1 st ed. BCTF publications, Dhaka-1000, Bangladesh. 514 pp.

Bashar, M. A. 2015. Butterflies of Bangladesh: A broad approach for nature lovers. Vol. 2. 1 st ed. BCTF publications, Dhaka-1000, Bangladesh. 177 pp.

Borror, D. J., C. A. Triplehorn and N. F. Johnson. 1989. An introduction to the study of insects. 6th ed. Saunders College Publishers, Philadelphia, USA. 875 pp.

Chowdhury, M. A. K. 2020. Foraging behaviour of some papilionid butterflies in Bhawal and Madhupur sal forests of Bangladesh. J. biodivers. conserv. bioresour. manag. 6(2): 55-68.

Danks, H. V. 1996. How to assess insect biodiversity without wasting your time. Biol. Surv. Canada (Terrestrial Arthropods), Document Series. 5(12): 1-22.

Dicke, M. 2017. Ecosystem services of insects. In: Van Huis, A. and Tomberlin, Directives. Biodivers. Conserv. 2: 258-282.

Gerlach, J., M. Samways and J. Pryke. 2013. Terrestrial invertebrates as bioindicators: An overview of available taxonomic groups. J. Insect Conserv. 17: 831-850.

Forister, M. L., E. M. Pelton and S. H. Black. 2019. Declines in insect abundance and diversity: We know enough to act now. Conservation Science and Practice. 1(8): 1-8.

Gullan, P. J. and P. S. Cranston. 2010. The Insects: An Outline of Entomology. 4th ed. Wiley-Blackwell, Oxford, UK. 584 pp.

Jankielsohn, A. 2018. The Importance of Insects in Agricultural Ecosystems. Adv. Entomol. 6(2): 62-73.

Jasmin, R. and M. I. Miah. 2013. Taxonomy of bees of Bangladesh forest Research institute campus, Chittagong, Bangladesh. Bangladesh J. Forest Sci. 32(2): 1-14.

Kirkman, T. W. 1996. Statistics to Use. http://www.physics.csbsju.edu/stats.

Klein, A. M., B. E. Vaissiere, J. H. Cane, I. Steffan-Dewenter, S. A. Cunningham, C. Kremen and T. Tscharntke. 2007. Importance of pollinators in changing landscapes for world crops. Proc. R. Soc. London B. Biol. Sci. 274: 303-313.

Kulshrestha, R. and N. Jain. 2016. A note on the biodiversity of insects collected from a college campus of Jhalawar district, Rajastan. Biosci. Biotech. Res. Comm. 9(2): 327-330.

Losey, J. E. and M. Vaughan. 2006. The economic value of ecological services by insects. BioScience. 56: 311-323.

Nasiruddin, M. and A. Barua. 2018. Odonate abundance and diversity in four selective spots of Chittagong University campus. J. biodivers. conserv. bioresour. manag. 4(1): 55-62

Nasiruddin, M. and H. Hoque. 2015. Abundance and diversity of insect fauna in four spots of Chittagong University Campus. J. biodivers. conserv. bioresour. manag. 1(1): 83-92.

Paul, S. K., M. Ahmed, M. S. A. Mamun and M. J. Alam. 2017. Diversity of insect, mite and nematode species in tea ecosystem of Bangladesh. J. biodivers. conserv. bioresour. Manag. 3(1): 31-44

Rahman, M. M. and M. N. Jahan.2020. Species diversity and richness of ant (Hymenoptera, Formicidae) in Bhawal National Park of Bangladesh. Bangladesh J. Agri. Res. 44(4):679-688. 
Ramar, M., M. Mahendran, S. Kamalakannan, E. Jayakumar, V. Anbalagan and K. Murugan. 2018. Biodiversity of insects and distribution pattern from Sirumallai Hills, Eastern Ghats, Tamil Nadu, South India. Biodivers. Int. J. 2(6): 495-498.

Usha, A. U. I. and K. J. Vimala. 2015. A study on Insect diversity of a selected area in Wadakkanchery district, Thrissur, Kerala. J. Zool. Stud. 2(3): 38-50.

Wahizatul, A. A., S. H. Long and A. Ahmad. 2011. Composition and distribution of aquatic insect communities in relation to water quality in two freshwater streams of Hulu Terengganu, Terengganu. J. Sustainability Sci. Manage. 6(1): 148-155.

Wessa, P. 2007. Free Statistics Software. Office for Research Development and Education, version 1-121. http:// www.wessa.net.

Woodcock, B. A., C. Harrower, J. Redhead, M. Edwards, A. J. Vanbergen, M. S. Heard, D. B. Roy and R. F. Pywell. 2014. National Patterns of Functional Diversity and Redundancy in Predatory Ground Beetles and Bees Associated with Key UK Arable Crops. J. Appl. Ecol. 51: 142-151.

Yi, Z., F. Jinchao, X. Dayuan, S. Weiguo and J. C. Axmacher. 2012. A Comparison of terrestrial arthropods sampling methods. J. Res. Ecol. 3: 174-182.

Zakaria H., S. Benhissen, W. Habbachi, F. Masna, A. Y. Asloum, S. Ben Lemkherbeche and K. Rebbas. 2021. Inventory of insects in the El Ghrous's palm grove (Biskra; Algeria). J. biodivers. conserv. bioresour. manag. 7(1): 85-94. 